\title{
THE HISTORICAL-ETHNOGRAPHIC IMAGE OF THE DRINKING PEOPLES OF THE NORTH
}

\author{
Art Leete
}

\begin{abstract}
In this paper I aim to analyse descriptions of Arctic peoples' drinking as one of the oldest stereotypes concerning inhabitants of the North. I intend to explore philosophical frameworks and ways of observation that influenced the appearance and maintenance of the image of a drinking northerner in literature through the millennia. I have examined different sources that provide descriptions of northern drinking as well as scientific and philosophical texts that reveal how the image of indigenous people and drinking is introduced and supported in the writings of intellectuals in different time periods. I have discovered that since classical antiquity, scholars and travellers have believed that people drink more in the north than they do in the south. Later on, medieval and Enlightenment authors developed this understanding about northern drinking according to religious and philosophical paradigms of their eras. My evidence also shows that drinking was included in the mainstream intellectual discourse concerning the Arctic since the 19th century. From the evidence, I conclude that the appearance and long-term survival of the ethnographic image of a drinking native of the North has been possible because of adaptation of this idea to specific temporary narrative strategies. In different periods this idea of Arctic drinking has been applied to specific theoretical and philosophical settings. This adaptability has made the idea about drinking in the North a rather powerful cognitive model of the northern indigenous peoples.
\end{abstract}

Keywords: alcohol, drinking, image, narrative, northern peoples

\section{INTRODUCTION}

The image of a drinking inhabitant of the North has been established in intellectual tradition, lasting since classical antiquity. During recent centuries, different authors have continued to depict drinking among the Arctic peoples as a characteristic and disturbing element of local life. As one of the most long-standing documented problems among the northern peoples, this theme serves to be explored in order to establish possible circumstances of persistent narrative reflections on drinking.

Western intellectuals depicted the Arctic predominantly as a space of euphoric mysticism and romantic heroism (see Lopez 1986). Drinking constitutes 
a concentration point of social problems, thus presenting quite a different angle on the northern regions and exhibiting the northern areas as arenas of sharp social and cultural ambivalence. In the framework of the current study, I approach the northern regions of the world in a rather wide perspective. As descriptions of northern drinking are not often related to specifically defined places in the 'North' or 'Arctic', my use of these concepts is intentionally vague. Older historical and philosophical sources constitute a general conceptual framework of understanding that those peoples that live in the northern side always drink more. I contend that arguments concerning a particular people's habits are derived from this indistinct notion. While analysing modern ethnographic discourse, I concentrate on indigenous groups of Western Siberia and the tundra areas of European Russia (the Nenets, Khanty and Mansi people).

As the topic involves sensitive ethical issues, drinking in the Arctic is not part of a usual contemporary ethnographic discourse. Even if ethnographers who have studied Western Siberia describe the devastating effects of systematic and extensive alcohol consumption in their diaries (see, e.g., Sokolova 2011) or indigenous people being sometimes just tipsy and joyful (see Chernetsov 1987), one cannot find any notions on drinking in their academic works (cf., e.g., Chernetsov 1959; Sokolova 1968, 1972) or popular overviews (see Sokolova 1976, 1981, 1982). In fact, earlier academic works are also characterised by the absence of the analysis of drinking. At the same time, descriptions of alcohol consumption were usually included in the field diaries and popular overviews of the northern peoples' lives.

I am not concentrating my study ${ }^{1}$ on actual drinking practices in the North, although these constitute an important frame of reality for my study. In this article I aim to analyse how drinking in the Arctic has been depicted and explained in early ethnographic literature. My argument is that modern descriptions of drinking among the northern peoples received prominent discursive support from the Western philosophical tradition. I intend to demonstrate the way in which this powerful image of drinking northerners has evolved and what kind of intellectual cognitive rules have shaped the development of this persistent image. I also investigate methods of reasoning about the northern indigenes being unable to resist alcohol.

\section{GROUNDING DISCOURSES OF NORTHERN DRINKING}

Modern academic discourse on the anthropology of drinking recognises the deep historical roots and the widespread nature of alcohol-related social practices. In many cultures, alcohol is used for arousing bodily sensations, arranging 
ritual actions, and confirming social relationships. Alcohol-related practices are surrounded with cultural paradoxes, and are valued both positively and negatively, concentrating around themselves a variety of ethnocentric assumptions (Mandelbaum 1979: 14; Heath 1987: 99-100, 106; Dietler 2006: 230-232, 242).

Significantly for the anthropology of drinking, a peculiar link has been recognised between the indigenous and geographic aspects of drinking. Similarly to the general alcohol discourse, these specific practices of drinking have been mapped among the earliest distinctive features of exotic cultures as such:

Since classical times, travellers from the oecumene [the known world] crossing the frontiers of civilization have noted, among other exotic phenomena, the way native people use alcoholic beverages and respond to drunkenness. (Honigmann 1979: 30)

One can find notions of drinking in very early descriptions of people, living far from centres of civilisation. Herodotus wrote in the 5th century B.C. about the Budin people living in the north and east of the Black Sea as great worshippers of Dionysus or Bacchus (Herodotus 1981 [1954]).

In his book titled Laws, Plato (4th century B.C.) describes the law of the Carthaginians stipulating that "[---] no one while he is on a campaign should be allowed to taste wine at all, but that he should drink water during all that time, and that in the city no slave, male or female, should ever drink wine" (Plato ICA). Earlier in the same book, Plato compares drinking customs of different peoples. He concludes that the Thracians and the Scythians (both men and women) drink unmixed wine, but the Persians have more moderation (ibid.). Plato does not reflect explicitly on natural conditions but one can deduct a climatic pattern from his approach: the people living north of Greece are described as more heavy drinkers, and southern neighbours as neglecting wine consumption. This observation is in accord with Herodotus's notes on the people in the North, whose drinking habits impressed the early Greek historian.

Recognition of this geographical drinking pattern becomes more explicit in the works of Hippocrates (5th century B.C.) and Aristotle (4th century B.C.). They believed that environment shapes human culture as well as human psyche (Phares 1991: 24). Aristotle analyses in his book Politics the influence of climate on the form of political organisation. According to Aristotle, northerly winds support democracy (as in Greece) and southerly winds encourage oligarchy (as in Cartago). He also makes a few notations on the consequent relationship between climatic conditions, health issues, and drinking habits (Aristotle ICA).

The correlation between climate and drinking is more precisely elaborated by Hippocrates. He considers that the life of those people who live in cities opened to southerly winds and sun but protected from northerly winds is guided 
by a number of physiological peculiarities. Among other things, Hippocrates warns that drinking wine is especially tough for inhabitants of the cities with southerly winds:

A city that is exposed to hot winds (these are between the wintry rising, and the wintry setting of the sun), and to which these are peculiar, but which is sheltered from the north winds; in such a city [---] they do not eat nor drink much; drinking wine in particular, and more especially if carried to intoxication, is oppressive to them. (Hippocrates ICA)

In order to be correct, it must be admitted that Hippocrates does not approve of drinking in northerly wind areas either. But he is not so strict while discussing drinking in northern conditions. According to Hippocrates, the northern weather is related to looser norms and at least moderate drinking is allowed, as natural conditions enable this to some extent (ibid.).

Thus, Hippocrates argues that drinking in the northern areas is caused or enabled by a specific interaction between climate and the human organism. Although Hippocrates mostly associates his arguments with the harmfulness of drinking in southern areas, somehow an implicit justification of northern drinking can be detected in his scholarly speculations.

Some other classical historians have touched upon the remarkable drinking habits of the North. For example, of northernmost peoples, Strabo (beginning of the 1st century), describes the Sacae who engage in drunken, licentious revelries (Strabo 1903). Following Strabo, Tacitus (1st century), too, writes of the destructive influence of civilisation on barbarians in connection with the spread of alcohol (Tokarev 1978: 41; Honigmann 1979: 30). Tacitus characterises habits of life in Germania and points out that people have plenty of rest there because of a long winter. The inhabitants of Germania often organise festal meetings or political discussions and drink large quantities of alcohol during these events:

To pass an entire day and night in drinking disgraces no one. Their quarrels, as might be expected with intoxicated people, are seldom fought out with mere abuse, but commonly with wounds and bloodshed. Yet it is at their feasts that they generally consult on the reconciliation of enemies, on the forming of matrimonial alliances, on the choice of chiefs, finally even on peace and war, for they think that at no time is the mind more open to simplicity of purpose or more warmed to noble aspirations. A race without either natural or acquired cunning, they disclose their hidden thoughts in the freedom of the festivity. Thus the sentiments of all having been discovered and laid bare, the discussion is renewed on the following day, and from each occasion its own peculiar advantage is derived. They 
deliberate when they have no power to dissemble; they resolve when error is impossible. (Tacitus 1877)

These classical descriptions of regions favourable for drinking were associated with the Greeks and Romans' neighbours and did not reach farther than Germany and the steppes around the Black Sea. But these regions constituted the border areas of the world, known to intellectuals of the Antiquity. Anyhow, by these descriptions and discussions, the matrix of northern drinking was established. During later periods, travellers and scholars shifted similar descriptions further to the real Arctic, but the standard was still borrowed from these classical accounts of alcohol practices. It must also be considered that these accounts were not simply reproduced but also developed further by adding new layers of meanings to these narratives.

During the Middle Ages, the overall descriptive style of the North remained the same as in the Antiquity. It was mostly due to the effect of the employed narrative strategy that resulted from the circumstance that many people who described the northern peoples had not actually met them (although they frequently claimed that they had). At the same time, descriptions of the Arctic obtained some specific features because real contacts with the northern peoples gradually became more frequent.

Descriptions of drinking became part of a dominant discourse that was aimed to confirm the Christian worldview. Sacred geography determined understanding of travel in spiritual terms. Regions far from the Christian world were supposed to be more sinful. This approach also included projecting drinking habits to the edge of the known world, and areas closer to Christian regions were supposed to follow biblical morals. For example, Eusebius of Caesarea (4th century) discusses the Law of Moses and demonstrates that Cartago laws, which prohibit drinking, are in accordance with evangelical principles (Eusebius of Caesarea 1903).

Another way to address drinking was to provide descriptions of the northern peoples who were rather fond of alcohol. For example, William of Rubrouck (1997: 151) wrote down a story he had heard from the Chinese priests in the 13th century about alcohol-liking savages who inhabited areas north of China. According to this narrative, if one manages to collect blood from these people while they are intoxicated, it is possible to make the colour purple.

In general, descriptions of the northern drinking in the Middle Ages repeated data provided in classical sources or retold stories heard during a few trips made by medieval travellers. At the same time, in contrast to the Ancient Greek and Roman authors, medieval writers shifted the meaning of these descriptions. The discourse of drinking in the North was shaped by Christian ideas about the moral inferiority of those using alcohol. Biblical allusions constituted a concep- 
tual core of these descriptions (Heath 1987: 106). Logically, only savages living far from the Christian world could tolerate this sinful practice.

\section{ENLIGHTENMENT PHILOSOPHY ABOUT DRINKING IN THE NORTH}

The tradition of thinking about a specific interrelationship between climate and drinking, initiated in ancient Greece, was developed further and introduced to modern Europe by Charles Montesquieu. Similarly to classical explanations, Montesquieu's theory connects southern areas (or regions closer to the equator) with oligarchy and strict laws (among them restrictions on drinking) that are determined by natural conditions. In northern lands (or the far south), drinking is more compatible with proper human behaviour. Classical Greek authors expressed this pattern in a moderate way but Montesquieu postulates a connection between climate and drinking rather firmly and clearly.

Montesquieu established an understanding of the relationship between climate and a style of culture for modern science, and a firm connection between climate, people's character, and political organisation. While discussing drinking-related laws, Montesquieu connects his thoughts to an earlier discourse, established for the scholarly tradition by Eusebius of Caesarea, Aristotle, and Plato.

Montesquieu argues that there exists an overall imminent connection between natural conditions and rules that shape different spheres of human life. According to Montesquieu, the spirit of people is a product of the phenomena governing them, such as climate, religion, laws and principles of the government, as well as past precedents, habits, and customs. Different governing phenomena can be found to predominate among different peoples. Savage peoples are governed exclusively by nature and climate (Montesquieu 1989: 290-291). Montesquieu is convinced that this interrelated natural and social establishment exists and scholars must be able to reveal the exact nature of this law:

If it is true that the character of the spirit and the passions of the heart are extremely different in the various climates, laws should be relative to the differences in these passions and to the differences in these characters. (ibid.: 231)

Other philosophers of the Enlightenment also promoted these ideas. For example, concurring with Montesquieu, Rousseau notes that natural factors characteristic of a climactic zone enable to determine the nature of the inhabitants of 
that region. Rousseau (1998: 110-112) maintains that cold climates are marked by barbarism and savagery.

Anyway, Montesquieu is the most prominent protagonist of the idea concerning climate and culture being tightly linked. According to Montesquieu, minds and passions are extremely different in different climatic zones. As Montesquieu (1989: 238-239) argues, in northern countries consumption of strong liquor is a necessity because of the cold climate.

Montesquieu also specifically discusses how drinking is related to conditions of nature. According to Montesquieu, the climate determines, among other things, physiological functions of a human body and thus also the drinking habits of a population. Exploring geographical determinants of human behaviour, he considers drinking physiologically inevitable in northern areas:

In cold countries, perspiration releases little of the watery part of the blood; it remains in abundance; therefore one can use spirits there without making the blood coagulate. One is full of humors there; alcoholic beverages, which give motion to the blood, are suitable. (Montesquieu 1989: 239)

Further, Montesquieu elaborates the debate, in particular the connection between religious or legal restrictions of drinking and climatic conditions in different regions. As he demonstrates, in the northern lands there exists an unavoidable need for drinking. People in these areas do not have a personal choice in developing their attitude towards drinking. The character of climate has determined it already:

The law of Mohammed that prohibits the drinking of wine is, therefore, a law of the climate of Arabia; thus, before Mohammed, water was the ordinary drink of the Arabs. The law that prohibits the Carthaginians from drinking wine was also a law of the climate; in effect, the climate of these two countries is about the same.

Such a law would not be good in cold countries, where the climate seems to force a certain drunkenness of the nation quite different from drunkenness of the person. (ibid.)

On the basis of the presented pieces of information, Montesquieu makes a comprehensive conclusion concerning worldwide drinking patterns. According to his theory, one can establish the degree of alcohol consumption of a population by estimating its position in regard to the equator and poles:

Drunkenness is found established around the world in proportion to the cold and dampness of the climate. As you go from the equator to our pole, you will see drunkenness increase with the degree of latitude. As you go 
from the same equator to the opposite pole, you will find drunkenness to the south, as on our side to the north. (ibid.)

It does not mean that we can necessarily observe differences in actual human behaviour. Natural conditions guide our conduct, but sometimes these differences are not explicit. Montesquieu argues that even if people in different geographic surroundings drink alike, their cultural choice must be contradictory. And these opposite cultural strategies may lead to adopting similar social practices concerning alcohol: "A German drinks by custom, a Spaniard by choice." (ibid.)

In general, Montesquieu's approach results in the argument that human beings make their own decisions concerning their actions, but climate serves as an overall determining force behind all human action. In this way, people are forced to incline towards certain kinds of habits. In the north, this package of ecological conduct includes, among other things, drinking.

After Montesquieu, descriptions of the northern peoples' drinking became rather usual in ethnographic accounts. Even if these observations were more structured and differently explained, a certain fatality permeates these 19thcentury reports. But all these accounts connect the geographical north and drinking according to the principal pattern proposed by Montesquieu.

\section{ACCOUNTS OF DRINKING AMONG NORTHERN PEOPLES AFTER MONTESQUIEU}

Sporadic scientific documentation of the northern peoples' drinking was also conducted in the 18th century, but this account was published much later, only in the mid-20th century (see Zuev 1947: 23). In the 19th century, ethnographies on Western Siberian indigenous groups became more frequent than before. Also, numerous travelogues about Siberia were published during this period. The issue of alcohol consumption was frequently touched upon.

Enlightenment philosophy had a certain influence on this line of thought in the ethnographies of the North. Enlightenment-inspired cognition of a specific pattern of northern drinking grounded a number of later descriptions. The 19th- and early 20th-century northern discursive tradition presupposed that in the North indigenous people are not able to resist alcohol. In general, this view continues Montesquieu's line of thinking.

In the 19th-century descriptions it became rather popular to present the image of an alcohol-loving northern people. Often, the possible reason of northern drinking is not proposed. Contemporary accounts were marked by a general perception of northern peoples as heavy drinkers. Quite a few authors 
in that period wrote about the Nenets' and Ob-Ugrians' love of liquor (Latkin 1853: 118; Castrén 1860: 265, 327, 340; 1967: 133-134²; Venyamin 1858: 82; Maksimov 1909a [1859]: 379-380; 1909b [1859]: 109; Sorokin 1873: 33; Simonov 1884: 387; Martin 1897: 11; Karjalainen 1983: 22, 32, 33, 64-65, 78; Kannisto 1963: 71-73, 74, 150-151; Kannisto \& Liimola 1951: XVII-XVIII; Ramsey 1908: 464, 466; Lvov 1903: 19; Sno 1904: 13; Ostroumov 1904: 27; Kozmin 1913: 37; see also Balzer 1999: 47).

Understanding of fatality in the drinking practice in the Arctic is reflected in the style of these notions as those are presented beyond dispute. Authors do not question the nature of the habit and describe it with an abundance of overwhelming emotions. For example, Mattias Aleksanteri Castrén gives a short but particularly vivid account of Nenets drinking (Castrén 1967: 133-134), summing up with a statement: "A general drinking malaise has taken hold of these poor people."

Another 19th-century scholar, Vasily Latkin, comes to a similar conclusion by noting that "desire for strong liquors is characteristic of all savage tribes" (Latkin 1853: 121-122).

Russian scholar Alexander Dunin-Gorkavich is also rather definite while discussing drinking habits of the Khanty people. Dunin-Gorkavich (1904: 25) makes simple statements about this issue without any hesitation, for example: "Drinking is widely spread among all the indigenes." Sometimes he adds a few details that stress the moral inferiority of this habit, arguing that "drinking is the main vice of the indigenes" (ibid.: 33).

The northern natives are described as hopelessly addicted to alcohol but also other narcotic substances. Yadrintsev, another Siberian intellectual, considers the Siberian natives to be passionate, childlike, and in need of cheap, sparkling trinkets:

They seek instant gratification of feelings and desires. Narcosis of any kind, be it induced by tobacco, alcohol or opium, seduces them and hurls them into a passionate abandonment, and becomes a lethal habit. (Yadrintsev 1996: 29)

With reference to the Khanty's love of alcohol, Finnish prominent ethnographer Uuno Taavi Sirelius offers a famous aphorism that the local Russian population employed around the turn of the past century to characterise the Khanty: "An Ostyak will sell his soul for liquor." (Sirelius 1900: 13)

These examples reflect the general understanding among the 19th- and early 20th-century scholars and regional intellectuals that drinking is widely spread and deeply rooted among the northern indigenous groups. This conceptual agreement is overwhelming and authors seem to compete in proposing more 
colourful statements. The proposed examples indicate that this pattern for describing the drinking habits of people from the North is firmly established among the researchers of the period.

It seems rather usual for the 19th- and early 20th-century authors to stress a drinking habit as common among the Ob-Ugrians and Samoyeds. But we could also find a few exceptions from these overall descriptions of profound and unlimited drinking in the North. A couple of authors have documented regions where indigenous individuals, or even groups, managed to resist to this temptation. Finnish linguist Artturi Kannisto mentions that his sixty-six-year-old Mansi interpreter, Andrian Kharitonovich Matykov, whom he found on the Tavda River, rarely drank (Kannisto \& Liimola 1951: XX). Dunin-Gorkavich likewise writes about alcohol abuse and the deterioration of morals among the native communities. In his estimation, only the Kazym and Vakh Khanty were not heavy drinkers, the latter group including some who completely abstained from strong alcohol (Dunin-Gorkavich 1904: 7-8; 1994 [1908]: 41; 1995: 84). Castrén (1860: 78-79) makes a note that the Sami around Lake Inari keep their desires under control and are modest consumers of alcohol, at the same time appreciating the economic power of the alcohol trade. N. Kozmin (1913: 37) reports a case where a wealthy Samoyed made an oath and spent a month in the Solovets Monastery, restraining from vodka during that time. Also, the Tundra Nenets drink vodka rarely (Latkin 1853: 137).

If these researchers felt the need to point out exceptions, it reflects the issue that drinking was considered a routine practice for the Siberian indigenous peoples. At the same time, Dunin-Gorkavich distinguishes whole groups who were not addicted to alcohol. It means that drinking was not actually mapped and recognised as a completely dominant social action.

But in general, descriptions of widespread drinking dominate the discourse about the northern indigenes' leisure time habits. Besides generalised statements concerning native alcohol abuse, some authors also elaborate more on specific issues related to this social problem. One of these matters is related to the question of gender and age. It has been written of the Khanty and Nenets that, in addition to men and women, their elderly women, young girls, and small children were also fond of alcohol (Zuev 1947: 23; Castrén 1860: 134-136, 285; Maksimov 1909a [1859]: 379; Karjalainen 1983: 32-33; Sno 1904: 13). There are other 19th-century authors, too, writing about the spread of alcoholism among the Ob-Ugrian women and children (see Lehtonen 1974: 41).

Another distinguishable theme in this respect concerns the problems that native people got into because of alcohol intoxication. For example, DuninGorkavich (1996 [1911]: 33-35) provides a list of court cases, related to violations of law, committed by the Khanty and Nenets while being drunk. They had hit 
other people, vandalised a local jail by ripping off the guards' uniforms, and smashed their housemaster's dishes and windows, as well as sworn at officials.

As the 19th-century authors see it, alcohol makes northern peoples aggressive, which runs counter to their otherwise peaceful demeanour. Archimandrite Venyamin writes of the Nenets of the Mezen tundra that they get into fights or arguments, or kill each other on rare occasions, and when it does happen it is only after they have been deranged by excessive drinking and have lost their senses (Venyamin 1858: 82). It was written about the Mansi that they, too, were only able to overcome their inherent shyness under the influence of alcohol (see, e.g., Sorokin 1873: 33, 50; cf. a similar observation concerning the Sami in Castrén 1860: 76). Castrén (ibid.: 158) reports a case when a crowd of drunken Komi attacked him, considering Castrén a witch. He also describes a massive drunken fight, in which Nenets women also participated (ibid.: 144). Finnish scholar August Ahlqvist also describes this situation:

While drinking, he [a Mansi] may actually become enraged and it is dangerous to argue with him when he does. Luckily, he falls into this state only a few times a year, while visiting a town or a church. (Ahlqvist 1885: 171)

This observation made by Ahlqvist is significant, as it illuminates a discrepancy between descriptions of heavily addicted indigenes and their actual, rather limited possibilities to obtain alcohol during the Tsarist period. As he adequately noted, chances for the indigenous people to obtain alcohol were actually scarce because of their relatively infrequent social, economical, and political contact with urban centres.

Beginning in the 17 th century, writers documented merchants' usual practice to trade furs, fish, and reindeer for vodka in the North, also among the Komi, Samoyeds and Ob-Ugrians (see, e.g., La Martiniere 1911: 27, 31, 35, 47-52, 59; Latkin 1853: 106, 115, 121, 127, 150; Castrén 1860: 180-1823). During the 19th century, legal restrictions were applied to obstruct the uncontrolled alcohol trade in the North. In the 19th century the northernmost point of the legal alcohol trade was Berezovo, and the other trading centre in Obdorsk was established only at the end of the century. Earlier, trade in Obdorsk had been concentrated at fairs (Castrén 1860: 147, 181-182; Bartenev 1896: 31). The government had prohibited the trade of alcohol among the northern people (Ahlqvist 1885: 171; Sno 1904: 13). At the beginning of the 20th century, a partial state monopoly of the alcohol trade was established in Surgut and Berezovo district, but, as Dunin-Gorkavich estimates, it caused only a hike in prices and spoiling the quality of vodka even more by the merchants (Dunin-Gorkavich 1904: 37; 1994 [1908]: 39)4 . Castrén (1860: 170, 325) summarises this style of 
trade by noting that vodka is "the Siberian amulet", a common denominator that enables one to trade anything.

It was also pointed out that the impact of cultural contacts played a considerable role in the spread and cultivation of alcoholism among the northern peoples, in particular towards the end of the Tsarist period. By virtue of their contacts with Russians and the Izva Komi, the Ob-Ugrians and Nenets began to be described as heavy consumers of alcohol, and as helpless, imprudent creatures who were therefore inevitably destined for destruction (Islavin 1847: 21-22; Vereshchagin 1849: 263; Castrén 1860: 146-147, 155, 194, 285; Jacobi 1896: 268; Dunin-Gorkavich 1904: 35; 1995 [1903]: 84, 130-139; Sno 1904: 10, 13; Kozmin 1913: 15-18; Anuchin 1916: 23) . Castrén (1860: 174) describes also the tundra Komi as heavy drinkers of vodka.

Throughout the 19 th to early 20 th centuries, descriptions of northern indigenous people's drinking habits were rather numerous. Alcohol became a common topic in scholars' and travellers' written reports about indigenous life in the wilderness of the Russian North and Siberia. These narratives describe drinking as a common practice among the northern natives. Besides the general portrayal of the nature of indigenous drinking habits, these accounts also include examinations of the specific aspects of this addiction (issues of gender and age, the drastic change of temper of the natives, and social and economic contacts that frame the distribution of drinking among the indigenous population).

From today's point of view, these descriptions seem to be exaggerated and articulated by the 19th-century authors because of the Enlightenment-influenced evolutionary philosophical frame they vaguely share. These intellectuals had, perhaps, pre-conceived ideas about a spoiled idyll or the inevitability of drinking in the North. Also, specific observed conditions could have led the authors to these rather one-sided conclusions. As the scholars of the 19th century rarely visited places beyond the bigger settlements, they were limited to observing indigenous people predominantly in towns and larger villages where the natives had much better access to alcohol. But it must also be admitted that these scholars described their impressions quite frankly and because of this attitude they documented valuable data concerning social trends of indigenous alcohol consumption of that period.

\section{DISCUSSION}

Narratives about drinking in the Arctic are not just a list of descriptions through time. The topic indicates significant conceptual developments over different periods. During Antiquity, complex intellectual views were elaborated concerning 
the interconnectedness of climate, political system, and drinking. Medieval writers conducted their interpretation of drinking in a biblical framework. Several modern philosophers, travellers, and scientists started to reinterpret classical views on inevitable drinking in the North. During the 19th century, a more socially sensitive view was developed, as some authors voiced the proposition of regarding alcohol-addicted northern natives as victims of colonialism (see Honigmann 1979).

Early discussions of northern drinking established a historical context for later alcohol studies in the Arctic. Analysis of these historical-ethnographic descriptions and philosophical arguments makes it possible to draw a few general conclusions. These remarks enable one to understand how ideas and images of northern drinking habits are bound together into a distinctive narrative. Besides, these early notes on Arctic alcohol practices reflect overall ways of describing peoples of the North from a specific angle.

Firstly, it can be pointed out that 19th-century scholars conducted a search for multiple causes of drinking, but their empirical observations of alcohol use by the indigenous people were actually rather fragmentary. 19th-century travellers and academics proposed a variety of causes for explaining drinking among the indigenous peoples of the North. During this period descriptions of drinking were exclusively extensive in published accounts of the northern human population.

It can be pointed out that accounts of unchecked alcoholism among northern peoples have been inspired by superficial impressions of the scholars who travelled in Siberia. Local natives were encountered chiefly in towns and at fairs, and in those settings the representatives of northern peoples were occasionally given to drinking. Most of the time, however, they were sober. Living in the forests for months at a time as they did, vodka was unavailable. It was much more readily available among the southern Ob-Ugrians, but harder to procure in the northern areas (Ahlqvist 1885: 171; Lehtonen 1974: 42-43). These observations indicate that drinking was in a few cases understood as "a symbolic punctuation mark differentiating one social context from another" (cf. Mandelbaum 1979: 16; see also Dietler 2006: 235). During the period under discussion, accounts of the natives' propensity for drinking were connected to the general idea held by the scholars that northern peoples were facing extinction in which alcoholism formed just one, albeit a rather telling, factor.

The factors that caught the attention of the 19th-century travellers and scholars were related to issues of gender- and age-specific drinking patterns, aggressiveness, and troubles caused by alcohol consumption, as well as deviations from the general drinking habit. The emotional consequences of drink, which may vary from aggressiveness to affection, are regulated by cultural 
expectations. In common understanding, but also in scholarly literature of a later period, drinking is regarded cross-culturally less acceptable for women than for men. Also the physiological effects attributed to alcohol are considered distinctive among different peoples (see Mandelbaum 1979: 15-19; Heath 1987: 102, 107-110; Dietler 2006: 235-236, 241).

The explanations proposed for the alcohol problem in the North by 19th-century authors included pressure from the alcohol trade (cf. discussion concerning the role of colonial culture contacts in spreading drinking among the indigenous peoples in Honigmann 1979; Heath 1987: 109; Dietler 2006: 232-234), and indigenous peoples natural affection towards intoxicating substances. Specific local cultural patterns of alcohol use as part of a larger cultural configuration were not actually discussed or even mentioned during this rather long period (cf. Mandelbaum 1979: 14-15; Honigmann 1979: 34; Heath 1987: 101; Dietler 2006: 237-241).

Secondly, it is possible to detect traces of 'Montesquieu's pattern' of global perspective in the 19th-century descriptions of alcohol consumption in the Arctic. This model of imagining different peoples' drinking habits is somehow reflected in Alfred Brehm's (1891) approach. He compares three indigenous peoples from the equator to the Arctic and shows that a certain gradation can be detected with respect to drinking. Brehm does not mention any drinking habits among the Nubians of the Upper Nile, describes drinking as a ritual practice among the Kyrgyz, and elaborates with an in-depth analyses of extensive drinking among the Khanty people. Although Brehm does not refer to Montesquieuan geographic determinism in this respect, the coincident of providing a similar behavioural pattern is somehow telling.

The dominant northern narrative of alcohol consumption is also supported by historical evidence, provided by Michael Dietler (2006: 234). Dietler highlights the beginning of increased recreational production and consumption of cheap sugar- and grain-based alcohol in the 16th-century Northern Europe. Other 19th-century scholars do not mention Montesquieu or classical authors as their theoretical sources. Also, nobody argues explicitly that the drinking habits of the northern people are caused by the climate or the 'wind'. By itself, this absence of references is not conclusive. The contemporary scholarly tradition did not necessarily require references to early authors while elaborating discussion on any subject matter (cf. Lotman 1964; Bakhtin 2000). The concept of specific regional patterns of drinking culture was borrowed from earlier travellers and scholars by later researchers (Honigmann 1979: 30). A kind of continuity in detecting culturally specific drinking patterns has also been recognised in later research. These cultural niches cover many separate societies and have main- 
tained remarkable consistency through time, from ancient indigenous cultures to contemporary societies (Mandelbaum 1979: 23).

Reflections on northern peoples' drinking habits became usual during the 19 th century (but were initiated already in the 1770s by Vasily Zuev). The topic of alcohol consumption was 'in the air' for many scholars at that time. There may well be a kind of cognitive link between the re-appearance of the semihidden theoretical discourse and increasing interest in empirical descriptions of northern drinking habits.

Descriptions of northern drinking habits can be seen as part of the same 'turn to cognitive diversity', which was developed by scholars during the 19th century. Travellers and academics started to describe many more aspects of the northern peoples' cultures than their colleagues had done during earlier centuries. Analogically, the other new or rediscovered themes of descriptions (the northern natives being modest, silent, intellectually less developed, etc.) were linked to contemporary philosophical discussions, in most cases implicitly, with just a few relevant references to more or less obvious theoretical or historical sources. This general approach was in accordance with intellectual traditions of the period, as making comprehensive references was not part of the academic demands of the time.

Thirdly, it is relevant to consider that the possible Montesquieuan inspiration became overshadowed by evolutionist intellectual practice in the northern peoples' descriptions of the 19th century. A majority of these drinking descriptions were produced in the framework of progress-inspired academic discourse, which envisioned indigenous social changes as a logical regression. Already Edward Tylor (1920: 53) argued that, from the initial encounter, civilisation spoils the natives. Also Herbert Spencer (1897), a prominent philosopher of the 19th century, argued that the desires of savage peoples direct their personal satisfaction and define their joyful and untroubled lifestyle.

These descriptions of northern drinking patterns can be interpreted as expressions of specific cultural barriers, extreme stereotypes, and ethnocentrism; yet, they are fully acceptable in the earlier research (see Honigmann 1979: 32-33; Heath 1987: 106; Leete 2005, 2014a). Later on, recognised ethical considerations changed in academic society and these descriptions of alcohol consumption in general disappeared from public scholarly accounts. Besides, the Soviet ideology that also shaped ethnographic accounts prescribed the approach that indigenous drinking remained in the past; it was a social evil of the Tsarist time. In fact, the situation with drinking for the indigenous North aggravated considerably (see, e.g., Sokolova 2011). Every ethnographer who has visited the Russian North can corroborate that this is still a painful and sensitive social issue in the region. 
I have demonstrated in my study that drinking in the Arctic has been described rather similarly during many centuries but explained by different arguments in early travellers' accounts as well as in philosophical and theoretical literature. In this paper I have discussed the ways in which this long-lasting image of drinking northerners has evolved since classical antiquity. Northern drinking was initially explained by a specific influence of the northern climate, which enables people to drink more freely than in southern regions, or even force them to consume alcohol. In medieval times, drinking was included in the spiritual map of the world and imagined as a characteristic practice for inhabitants of the sinful periphery of the oecumene. Beginning in the 18th century scholars looked to the past, searching for materialistic, natural reasons for the northern peculiarities of alcohol consumption.

The proposed evidence reveals that different authors basically repeat previous data concerned with drinking over a long period of time. At the same time, this continuation is not mechanical but driven by specific motivators and a changing methodological framework. The most long-term frame of explanation, shared by scholars, has been related to interpreting geography and climatic conditions as prominent determinants of culture. Another aspect of this long-term continuation of descriptions is related to the writing method that prescribed the repetition of earlier authors as a criterion of truth (see Lotman 1964). In the 19th century, evolutionary theoretical ideas and more frequent contacts with indigenous groups in the North enabled to produce a seemingly more evidence-based image of the northern peoples. But interestingly, this new cognitive model included similar descriptions of extensive drinking.

Drinking among the indigenous societies of the North is a social problem, but also an aspect of ritual behaviour (see, e.g., Leete 1997, 2004, 2014b; Wiget \& Balalaeva 2011; Toulouze \& Niglas 2012; cf. Mandelbaum 1979: 15, 19; Heath 1987: 108-109; Dietler 2006: 241). But as we can conclude from the presented evidence, drinking is also one of the oldest topics discussed in regard to the northern peoples' image. It has long been a habit of travellers and scholars to consider drinking as a meaningful practice, characterising life in the Arctic regions.

The initial philosophical meaning of the descriptions of drinking is lost in the course of ethnographic textual practices. Anyhow, it seems that some connotation still remains in regard to original texts, and this textual practice survives through long time periods. Descriptions of drinking often serve as extended poetic metaphors, illustrating a continuous stability of northern images. Real problems of social change, as well as economic and historical developments, are also reflected in these notions. 


\section{NOTES}

1 This research was supported by the European Union through the European Regional Development Fund (Centre of Excellence in Cultural Theory, CECT) and the Estonian Research Council (grant PUT590).

${ }^{2}$ In his diary Castrén also regularly reports about the Sami drinking (1860: 32, 72-73, 76).

3 Castrén (1860: 20, 43) describes trading vodka for folklore and linguistic evidence (but also for transportation during a field-trip) among the Sami as a usual academic approach, Vasily Latkin's travel report consists of descriptions of episodes about how he keeps a friendly relationship with the Komi by providing them with vodka (Latkin 1853: 78, 80).

4 Castrén (1860: 79) argues that vodka is "the all-conquering negotiator" among the Sami.

5 Ostroumov (1904: 22) reports that figures of indigenous gods were also traded for vodka in the north.

\section{REFERENCES}

Ahlqvist, August 1885. Unter Wogulen und Ostjaken: Reisebriefe und ethnographische Mittheilungen. Acta Societatis Scientiarium Fennicae XIV, pp. 133-308. Available at https://archive.org/details/actasocietatissc141885suom, last accessed on June 16, 2015.

Anuchin 1916 = Anuchin, Vasilii. V strane chernykh dnei $i$ belykh nochei (Turukhanskii krai). [In the Land of Dark Days and White Nights (Turukhansk Region).] Znanie dlia vsekh: Obshchedostupnyi zhurnal dlia samoobrazovaniia s kartinami v kraskakh i illiustratsiiami v tekste. [Knowledge for Everybody: Generally Approachable Journal for Self-Education with Coloured Pictures and Illustrations in the Text.] Petrograd: Izd. P.P. Soikina.

Aristotle ICA = Aristotle. Politics. Transl. by Benjamin Jowett. The Internet Classics Archive. Available at http://classics.mit.edu//Aristotle/politics.html, last accessed on June 12, 2015.

Bakhtin, Mikhail 2000. The Dialogic Imagination: Four Essays. Austin: University of Texas Press.

Balzer, Marjorie Mandelstam 1999. The Tenacity of Ethnicity: A Siberian Saga in Global Perspective. Princeton: Princeton University Press.

Bartenev, Viktor 1896. Na krainem Severo-Zapade Sibiri: Ocherki Obdorskogo kraia. [On the Far North-West of Siberia: Essays about the Obdorsk Region.] SanktPeterburg: Tipografiia M. F. Paikina.

Brehm 1891 = Brem, Al'fred Edmund. Zhizn' na Severe $i$ Iuge: ot polusa do ekvatora . [Life in the North and South: From Pole to Equator.] Sankt-Peterburg: Izd. F. Pavlenkova. 
Castrén 1860 = Kastren, Aleksander. Puteshestvie Aleksandra Kastrena po Laplandii, severnoi Rossii i Sibiri (1838-1844, 1845-1849). [Travels of Alexander Castrén in Lapland, Northern Russia and Siberia (1838-1844, 1845-1849).] Magazin zemlevedeniia i puteshestvii. Geogr. sbornik N. Frolova. T. 6. Sobranie starykh i novykh puteshestvii. Ch. 2. Moskva: n.p.

Castrén, Matias Aleksanteri 1967. Tutkimusmatkoilla Pohjolassa. [Research Trips to the North.] Porvoo, Helsinki: WSOY.

Chernetsov 1959 = Chernetsov, Valerii. Predstavleniia o dushe u obskikh ugrov. [Concepts of Soul among the Ob-Ugrians.] Trudy Instituta Etnografii, T. 51. Moskva: Institut Etnografii im. N.N. Miklukho-Maklaia.

Chernetsov 1987 = Chernetsov, Valerii. Istochniki po etnografii zapadnoi Sibiri. [Ethnographic Sources about the Western Siberia.] Tomsk: Izdatel'stvo Tomskogo universiteta.

Dietler, Michael 2006. Alcohol: Anthropological/Archaeological Perspectives. Annual Review of Anthropology, Vol. 35, pp. 229-249. http://dx.doi.org/10.1146/annurev. anthro.35.081705.123120.

Dunin-Gorkavich, Alexandr 1904. Ocherk narodnostei Tobol'skogo severa. [Essay about the Peoples of the Tobolsk North.] Sankt-Peterburg: Tipografiia M.Stasiulevicha. Available at http://www.rulit.me/books/ocherk-narodnostej-tobolskogo-severaget-375733.html, last accessed on June 16, 2015.

Dunin-Gorkavich, Alexandr 1994 [1908]. Nuzhdy Tobol'skogo severa i mery dlia ikh udovletvoreniia. [Needs of the Tobolsk North and Means of Their Satisfaction.] Shadrinsk: Iset'.

Dunin-Gorkavich, Alexandr 1995 [1903]. Tobol'skii Sever: Obshchii obzor strany, ee estestvennykh bogatstv i promyshlennoi deiatel'nosti naseleniia. [Tobolsk North: Overview of the Land, Its Natural Riches and Industrial Activity.] T. 1. Moskva: Libereia.

Dunin-Gorkavich, Alexandr 1996 [1911]. Tobol'skii Sever: Etnograficheskii ocherk mestnykh inorodtsev. [Tobolsk North: Ethnographic Essay about Local Indigenes.] T. 3. Moskva: Libereia.

Eusebius of Caesarea 1903. Praeparatio Evangelica. [Preparation for the Gospel.] Transl. by E.H. Gifford. Oxonii: E Typographeo Academico. Available at http://www. ccel.org/ccel/pearse/morefathers/files/eusebius_pe_00_intro.htm, last accessed on June 16, 2015.

Heath, Dwight B. 1987. Anthropology and Alcohol Studies: Current Issues. Annual Review of Anthropology, Vol. 16, pp. 99-120. http://dx.doi.org/10.1146/annurev. an.16.100187.000531.

Herodotus 1981 [1954]. The Histories. Transl. by Aubrey Sélincourt. London: Penguin Books.

Hippocrates ICA = Hippocrates. On Airs, Waters, and Places. Transl. by Francis Adams. The Internet Classics Archive. Available at http://classics.mit.edu//Hippocrates/ airwatpl.html, last accessed on June 12, 2015.

Honigmann, John J. 1979. Alcohol in Its Cultural Context. In: Mac Marshall (ed.) Beliefs, Behaviors, and Alcoholic Beverages: A Cross-Cultural Survey. Ann Arbor: The University of Michigan Press, pp. 30-35. 
Islavin, Vladimir 1847. Samoedy $v$ domashnem $i$ obshchestvennom bytu. [Samoyeds in Private and Social Life.] Sankt-Peterburg: Tipografia Ministerstva gosudarstvennykh imushchestv. Available at http://webirbis.aonb.ru/irbisdoc/kr/2012/07kp138. pdf, last accessed on June 17, 2015.

Jacobi 1896 = Iakobii, Arkadii. Ugasanie inorodcheskikh plemen Tobol'skogo severa. [Decline of Indigenous Tribes in the Tobolsk North.] Zhivaia starina, Nos. 3-4, pp. 267-272. Available at http://antropo-logica.com/pdf/jacobii.pdf, last accessed on June 17, 2015.

Kannisto, Artturi \& Liimola, Matti 1951. Wogulische Volksdichtung I: Texte mythischen Inhalts. Ges. und übers. von Artturi Kannisto, bearb. und hrsg. von Matti Liimola. Suomalais-ugrilaisen Seuran Toimituksia 101. Helsinki: Suomalais-Ugrilainen Seura.

Kannisto, Tytti (ed.) 1963. Artturi Kanniston tutkimusmatkat Siperiassa vuosina 19011906: Päiväkirjamuistiinpanoja ja kirjeitä. [Artturi Kannisto's Research Trips to Siberia during the Years 1901-1906: Diaries and Letters.] Suomalais-ugrilaisen Seuran Aikakauskirja, Vol. 64, No. 1.

Karjalainen, Kustaa Fredrik 1983. Ostjakit: Matkakirjeitä Siperiasta 1898-1902. [The Khanty: Travel Accounts from Siberia 1898-1902.] Suomalaisen Kirjallisuuden Seuran toimituksia 394. Helsinki: Suomalaisen Kirjallisuuden Seura.

Kozmin, Nikolai 1913. Arkhangel'skie samoedy (ocherk ikh byta i verovanii). [Samoeds of Arkhangelsk: Essay on Their Daily Life and Beliefs.] Sankt-Peterburg: Izdanie Uchilishchnago soveta pri Sviateishem Sinode.

La Martiniere 1911 = Lamartin'er, P'er-Martin de. Puteshestvie v severnye strany (1653 g.). [Journey to Northern Countries.] Moskva: Moskovskii arkheologicheskii institut.

Latkin 1853 = Latkin, Vasilii. Dnevnik Vasilia Nikolaevicha Latkina, vo vremia puteshestviia na Pechoru, v 1840 i 1843 godakh. Chast' pervaia. [Diaries of Vasily Nikolaevich Latkin, from the Time of His Travels to Pechora, in 1840 and 1843. First part.]. Zapiski imperatorskogo russkogo geograficheskogo obshchestva, kn. VII. Sankt Peterburg: Tipografiia Imperatorskoi Akademii Nauk. Available at http://www.booksite.ru/fulltext/komi/3703.pdf, last accessed on June 17, 2015.

Leete, Art 1997. Sacrificial Ceremony at Lake Num-To. Pro Ethnologia, Vol. 5, pp. 35-55. Available at http://www.erm.ee/pdf/PEnr5.pdf, last accessed on June 16, 2015.

Leete, Art 2004. Ritual, Politics and Mentality: The Nenets and Ob-Ugrians of Siberia. In: Anna-Leena Siikala \& Barbro Klein \& Stein R. Mathisen (eds.) Creating Diversities: Folklore, Religion and the Politics of Heritage. Studia Fennica: Folkloristica, Vol. 14. Helsinki: Finnish Literature Society, pp. 125-135. Available at http://www.academia.edu/2549002/Ritual_politics_and_mentality_the_Nenets_ and_Ob-Ugrians_of_Siberia, last accessed on June 17, 2015.

Leete, Art 2005. Accounts of Cannibalism, Human Sacrifice, Alcohol-Addiction and Filthiness among Northern Peoples. Acta Ethnographica Hungarica, Vol. 50, Nos. 1-3, pp. 241-258. http://dx.doi.org/10.1556/AEthn.50.2005.1-3.15.

Leete, Art 2014a. Guileless Indigenes and Hidden Passion: Descriptions of Ob-Ugrians and Samoyeds through the Centuries. Transl. by Katrin Hakkinen. Folklore Fellows Communications 306. Helsinki: Academia Scientiarium Fennica. 
Leete, Art 2014b. Sacrifices de rennes et pétrole: dialogue entre rituel et droits des peuples autochtones. [Reindeer Sacrifice and Oil: Dialogue between Indigenous Rights and Ritual.] Études finno-ougriennes, Vol. 46, pp. 57-88. Available at http:// www.academia.edu/11007592/Sacrifices_de_rennes_et_p\%C3\%A9trole_dialogue_ entre_rituel_et_droits_des_peuples_autochtones, last accessed on June 17, 2015.

Lehtonen, Juhani U.E. 1974. Kalan myyntiä ja viinan juontia: Kansatieteellinen tutkimus ostjakkien ruokataloudesta ja sen suhteesta ostjakkien talousmuotoon erityisesti 1800-luvulla. [Trading Fish and Getting Vodka: Ethnographic Study of the Khanty Food Economy and Its Relationship with the Khanty Economic Pattern, Especially during the 1800s.] Helsingin yliopiston kansatieteen laitoksen tutkimuksia 4. Helsinki: Helsingin yliopiston Kansatieteen laitos.

Lopez, Barry 1986. Arctic Dreams: Imagination and Desire in a Northern Landscape. New York: Vintage Books.

Lotman 1964 = Lotman, Iurii. Lektsii po struktural'noi poetike. Vyp. 1 (Vvedenie, teoriia stikha). [Lectures on Structural Poetics. Vol. I (Introduction, Theory of Verse).] Trudy po znakovym sistemam I. [Sign System Studies I.] Tartu: Tartu Riikliku Ülikooli Toimetised 160. Available at http://dspace.utlib.ee/dspace/handle/10062/41631, last accessed on June 17, 2015.

Lvov, Vladimir 1903. Samoedy (Ocherk). [The Samoyeds. (Essay).] Moskva: Tipo-lit. T-va I. N. Kushnerev i Ko.

Maksimov, Sergei 1909a [1859]. God na Severe. [Year in the North.] Chast'vtoraia. Sobranie sochinenii S. V. Maksimova. [Collected Works of S. V. Maksimov.] Tom IX. SanktPeterburg: Tovarishchestvo prosveshchenie. Available at http://www.booksite.ru/reise/ maks/imov/index.htm, last accessed on July 2, 2015.

Maksimov, Sergei 1909b [1859]. God na Severe. [Year in the North.] Chast'vtoraia. Sobranie sochinenii S. V. Maksimova. [Collected Works of S. V. Maksimov.] Tom X. Sankt-

Peterburg: Tovarishchestvo prosveshchenie. Available at http://www.booksite.ru/reise/ maks/imov/index.htm, last accessed on July 2, 2015.

Mandelbaum, David G. 1979. Alcohol and Culture. In: Mac Marshall (ed.) Beliefs, Behaviors, and Alcoholic Beverages: A Cross-Cultural Survey. Ann Arbor: The University of Michigan Press, pp. 14-30.

Martin, Fredrik Robert 1897. Sibirica: Ein Beitrag zur Kenntnis der Vorgeschichte und Kultur sibirischer Völker. Stockholm: Chelius.

Montesquieu, Charles 1989. The Spirit of the Laws. Cambridge \& New York \& Port Melbourne \& Madrid \& Cape Town: Cambridge University Press.

Ostroumov, Ivan G. 1904. Voguly-mansi: Istoriko-etnograficheskii ocherk. [Voguls-Mansi: Historical-Ethnographical Essay.] Perm': Tipografiia gazety "Permskii krai”.

Phares, E. Jerry 1991. Introduction to Personality. New York: Harper Collins.

Plato ICA = Plato. Laws. Transl. by Benjamin Jowett. The Internet Classics Archive. Available at http://classics.mit.edu//Plato/laws.html, last accessed on June 12, 2015.

Ramsey, William 1908. U samoedov Kaninskogo poluostrova. [Among the Samoyeds of the Kanin Peninsula.] Izvestiia Obshchestva arkheologii, istorii i etnografii pri Imperatorskom Kazanskom universitete, Vol. 23, Nos. 1-6, pp. pp. 458-471. 
Rousseau, Jean-Jacques 1998. Ühiskondlikust lepingust ehk riigiõiguse põhiprintsiibid. [The Social Contract.] Tallinn: Varrak.

Simonov, Leonid 1884. Vymiraiushchee plemia (Istorichesko-etnograficheskii ocherk). [Extinct Clan (Historical-Ethnographic Essay).] Zhivopisnoe Obozrenie, pp. 101-130, 249-280, 377-404. Available at https://vivaldi.nlr.ru/pm000020431/view\#page=1, last accessed on July 3, 2015.

Sirelius, Uuno Taavi 1900. Ostjakkilaiselta matkaltani v. 1898. [From the Khanty Trip in 1898.] Suomalais-ugrilaisen Seuran Aikakauskirja, Vol. 17, pp. 1-29.

Sno, E.E. 1904. Za Ural'skim khrebtom: sibirskie inorodtsy. [Beyond the Ural Mountains: The Siberian Indigenes.] Sankt-Peterburg: Izdatel'stvo O. N. Popovoi. Available at http://www.tmnlib.ru:82/files/base/books/RK/2011/Sno/index.html, last accessed on June 18, 2015.

Sokolova 1968 = Sokolova, Zoia. Preobrazovaniia v khoziaistve, kul'ture i byte obskikh ugrov . [Rearrangements in Economy, Culture and Household of the Ob-Ugrians.] Sovetskaia etnografiia, No. 5, pp. 25-39. Available at http://www.booksite.ru/etnogr/1968/1968_5. pdf, last accessed on June 18, 2015.

Sokolova 1972 = Sokolova, Zoia. Khanty rr. Syna i Kunovat: Etnograficheskii ocherk. [The Khanty of the Rivers Synya and Kunovat: Ethnographical Essay.] In: N. Lukina \& N. Tomilov (eds.) Materialy po etnografii Sibiri. [Materials about the Ethnography of Siberia.] Tomsk: Izdatel'stvo Tomskogo universiteta, pp. 15-66.

Sokolova 1976 = Sokolova, Zoia. Strana Iugoriia. [The Land of Yugra.] Moskva: Mysl'.

Sokolova 1981 = Sokolova, Zoia. Na prostorakh Sibiri. [In the Expanses of Siberia.] Moskva: Russkii iazyk.

Sokolova 1982 = Sokolova, Zoia. Puteshestvie v Iugru. [Travel to Yugra.] Moskva: Mysl'.

Sokolova 2011 = Sokolova, Zoia. Severnye khanty (Polevye dnevniki). [The Northern Khanty (Fieldwork Diaries).] Moskva: IEA RAN.

Sorokin, N. 1873. Puteshestvie $k$ vogulam: Otchet, predstavlennyi otdelu antropologii $i$ etnografii pri kazanskom obshchestve estestvoispytatelei. [Travel to the Mansi: Report Presented to the Department of Anthropology and Ethnography at the Kazan Society of Scientific Experimenters.] Trudy obshchestva estestvoispytatelei pri Imperatorskom Kazanskom Universitete. T. III, No. 4. Kazan': Kazanskii universitet.

Spencer, Herbert 1897. The Principles of Sociology. Vol. I. New York: D. Appleton and company.

Strabo 1903. The Geography of Strabo. London \& New York: George Bell \& Sons. Available at http://www.perseus.tufts.edu/hopper/text?doc=Perseus\%3Atext\%3 A1999.01.0239\%3Abook\%3Dnotice, last accessed on June 12, 2015.

Tacitus 1877. Excerpts from Germania. Available at http://legacy.fordham.edu/halsall/ source/tacitus-germania-excerp.html, last accessed on July 2, 2015.

Tokarev, Sergei 1978. Istoki etnograficheskoi nauki (do serediny XIX v.). [Sources of Ethnographical Research (Until Mid-19th C.).] Moskva: Nauka.

Toulouze, Eva \& Niglas, Liivo 2012. Native Spirituality in (Re)constructed Personhood: Observing and Filming Yuri Vella. Folklore: Electronic Journal of Folklore, Vol. 51, pp. 133-170. http://dx.doi.org/10.7592/FEJF2012.51.toulouze-niglas. 
Tylor, Edward Burnett 1920. Primitive Culture: Researches into the Development of Mythology, Philosophy, Religion, Language, Art, and Custom. Vol. 1. London: J. Murray. Available at https://archive.org/details/primitiveculture01tylouoft, last accessed on June 18, 2015.

Venyamin 1858 = Veniamin [Smirnov, Vasilii]. Samoedy mezenskie. [The Samoyeds of Mezen.] Etnograficheskii sbornik, izdavaemyi Imperatorskim Russkim Geograficheskim Obshchestvom, Vyp. IV, pp. 19-82.

Vereshchagin V. 1849 = Ocherki Arkhangel'skoi gubernii. [Essays about Arkhangelsk Guberniya.] Sankt-Peterburg. Available at http://yatbooks.ru/load/literatura po_gubernijam/arkhangelskaja/vereshhagin_ocherki_arkhangelskoj_ gubernii_1849g/3-1-0-160, last accessed on June 18, 2015.

Wiget, Andrew \& Balalaeva, Olga 2011. Khanty: People of the Taiga, Surviving the 20th Century. Fairbanks: University of Alaska Press.

William of Rubrouck 1997 = Vil'gel'm de Rubruk. Puteshestvie v vostochnye strany. [Travel to the Eastern Lands.] In: Kniga o raznoobrazii mira: Dzhovanni del' Plano Karpini. Istoriia mongalov. Gil'om de Rubruk. Puteshestviia v vostochnye strany. Kniga Marko Polo. Moskva: Mysl', pp. 86-189.

Yadrintsev 1996 = Iadrintsev, Nikolai. Sibir' kak koloniia. [Siberia as a Colony.] Iugra, No. 2, pp. 26-29.

Zuev 1947 = Zuev, Vasilii. Materialy po etnografii Sibiri XVIII veka (1771-1772). [Materials on Siberian Ethnography from the 18th Century (1771-1772).] Trudy Instituta Etnografii im N.N. Miklukho-Maklaia, T. 5. Moskva \& Leningrad: Izdatel'stvo Akademii Nauk SSSR. 